\title{
From a Vernacular Photograph to an Icon: The Spirited Face of Gezi Park Resistance*
}

\author{
Pelin Aytemiz \\ Başkent University, Ankara, Turkey
}

\begin{abstract}
During spring 2013, an important uprising had broken out and marked a historic period for political activism in Turkish memory. Focusing on the afterlives of photographic portraits produced during this "Occupy Gezi Movement", the paper considers iconized digital portraitures as a peculiar genre of vernacular photography and focuses on its visual language, and cultural codes as a part of the underground resisting culture in daily life. It explores different contexts in which photographic portraits have been used as a tool of protest and their various kinds of remediation from the Gezi Park Protest onwards. Private portraits as an agent of resistance have been creatively modified, recreated, rematerialized and circulated in distinct ways during and after the protest: from city walls as stencils, stickers, and graffiti (in actual public spaces) to Facebook profile walls as online digital re-mastering (virtual spheres). This article concentrates on aesthetics of such iconized digital photographic portraitures in contemporary Turkey. It particularly focuses on one of the instances that have labeled the Occupy Gezi Movement: the death of Berkin Elvan, who turned 15 while in a coma who has been struck in the head by a tear gas canister, fired by police, while on his way to buy bread. This case has been a catalyst for further demonstrations against Turkey's ruling party and turned Elvan's high-spirited face and dark eyebrows, to one of the strong symbols of the resistance. The teenage boy's injury during the protests, his birthday while he was in a coma at the hospital, his death, funeral and commemorations have been stress points in which his photographic portrait have been modified and redesigned according to the occasion and circulated widely. The image of the youth symbol of the struggle and the different kinds of cultural work his photograph have performed is the main focus of this research. The digital social afterlives of Elvan's iconized imagery as illustrations and drawings; as stencils and graffiti at streets; as posters and framed photographs in political performances carried around in public spaces and commemorative acts; and as digital data circulated in social media both consisting of indexical and iconic elements regarding their photographic features. This transformation of the single analog vernacular photograph of Elvan to various digital versions and continuous re-interpretation and re-materialization is discussed depending on the local history of the occasion and the critical literature on photographic history and theories of photographic vernacularity. This research makes use of data collecting methods that netnographic research methodology uses. The paper focuses on the ways local vernacularity is historically produced and evolved in this particular time of Gezi Park Resistance.
\end{abstract}

Keywords: vernacular photography, Berkin Elvan, Gezi Park Movement, icon, Turkish history

\footnotetext{
* An earlier version of this paper was presented in "Media Asia 2015: The Sixth Asian Conference on Media \& Mass Communication: Human Rights, Justice, Media and Culture" organized by The International Academic Forum in Kobe Japan between 2-16 November 2015.

Pelin Aytemiz, Ph.D., Assistant Professor, Department of Radio, TV and Cinema, Faculty of Communication, Başkent University.
} 
Stones and rubbles all around the streets, burning barricades... Running protesters into shops, cafés, and private apartments to flee the clouds of tear gas and water cannons... These scenes are from Turkey's biggest cities during spring 2013 where an important uprising had broken out and marked a historic period for political civil activism in Turkish memory. ${ }^{1}$ The protests of the "Occupy Gezi" movement started on the 28th of May in Istanbul over the plans of the Municipality to demolish one of Istanbul's rare central park called "Gezi". The protests aiming to preserve the green area started with a sit-in at the park and developed into an Occupy-like camp after the violent attack of the police. Subsequently,the movement spread to the major cities all over Turkey and turn into a nationwide rally against the AKP (Justice and Development Party) government. The demands of democratization coming from the protesters have varied according to a series of factors such as the political background, gender, the place of demonstration attended and so on. But the major reasons for the growing unrest was about the government's policies restricting individual freedoms: such as the new arrangements about abortion, curbs on alcohol, threats to the freedom of speech and freedom of the press, the recent row about kissing in public and the closing of the cultural centers. The movement also includes protests against the mainstream media that turn a blind eye to these groundbreaking events and the intense police violence. This Occupy Gezi movement started a burst of creative production with a variety of posters, banners and artworks appearing on the streets and on social media which have majorly used photography and humor, both in graffiti and online, as its main source material reflecting the new and fresh characteristic of the movement. Satire and irony especially criticizing the government, the prime minister and the police has been the powerful weapon of the protester used on streets and on social media. This paper focuses especially on the new visual language of the movement and the ways local vernacularity is historically produced and evolved in this particular time of Gezi Park Resistance. The visual language, the post-production and photo manipulation of digital portraitures produced by resistance groups are concentrated. More precisely those iconic images, which in a very broad sense made history during this time that is widely disseminated and recognized immediately is analyzed. This research aims to provide a theoretically informed account of the iconic photographs depending on the critical literature of photography and visual culture. Photographs circulated through social media communication, news coverage, and print journals mostly during summer 2013 are used for evaluation as a part of netnographic research methodology and also images taken by the author during the resistance and observations are also used as the source material. Focusing on the afterlives of photographic portraits produced during this "Occupy Gezi Movement" in such a tense atmosphere, this paper explores different contexts in which photographic portraits have been used as a tool of protest and their various kinds of remediation from the Gezi Park Protest onwards. The new political language of Gezi Park resistance that synthesize diverse referents reflecting the demographics of the young protesters combines the language of the ordinary borrowed from popular cultural texts such as films, TV serials, video games, poetry. Not only the streets that host the graffiti on the walls, but also, because of the photographs captured and shared through the instantaneous publishing in social media, the screens were loaded with humorous images and political and satirical slogans. During this time of "carnival", the movement turned streets walls to offline physical spaces and the screens to online virtual spaces of expression addressing various oppressive conditions the writers might be suffering from mostly targeting the police, politicians, and the media. The language of Gezi might be

\footnotetext{
${ }^{1}$ Ministry of Internal Affairs reports that two and a half million people took part in the uprising in seventy-nine cities of Turkey (Karakayal1, 2014).
} 
exemplified in these graffiti's in which one writes: "Enough! I'm calling the police". ${ }^{2}$ And in another also critiquing the police force a text is added over a blurred photograph of an activist throwing back the tear gas canister to the riot police, reads "Mr. Officer you dropped something!"3, or hailing the 25th prime minister and the chairman of the ruling Justice and Development Party (AKP) Tayyip Erdoğan says: "Don't be afraid, it is us, the people!"^4 One graffiti message, using "Sultan" as a reference to the absolute monarchs of the Ottoman Empire, is used to critique prime minister. Another one exclaimed: "Tayyip, winter is coming" as a pop cultural references to the famous contemporary TV series Game of Thrones. Referring to the popular video game one message read: "You picked the generation who beats up cops in Grand Theft Auto!", while also referring to the protesters young demographics. According to Perrin Emre through the usage of irony not only the graffiti or stencils on the walls or banners subverts the authorities discourse, but also the slogans shouted out during the protests such as "Yay, tear gas!" "Dude this gas is awesome!" also reflect the new festival-like characteristic of the protests (2014, p. 6). In this context, Christiane Gruber (2013) remarks that the tear gas and water cannons were being normalized, expected and even awaited. Like this slogan that invites the police to gas as if inviting them to dance, "Would you be so kind as to grant this gas to me? $?^{5}$, or addressing to the water cannons the protesters shouts: "We haven't had a shower for 3 days, where are you TOMA ${ }^{6}$ ?"7 (Çetin, 2013, p. 8). In this sense, Karakayalı and Yaka argues that the language that characterized the Gezi Resistance that is marked with humor is not only a sideshow or a decorative element of the protest but a powerful multitude tool that has a specific mechanism (2014, p. 120). Akin, Bülent Eken borrowing Mikhail Bakhtin's discussion of laughter as a subversive tool, argues that both new and contemporary language of the Gezi Movement is an indicator of the potential of becoming and works against the models of the national myth by flourishing parody (2014, p. 432). Extending these discussions, one can say that not only the verbal language but also the political language of the visuals from photographs to stencils and graffiti works has characterized the movement. This article argues that the visual language of the movement also have a potential of starting new conversations that communicate a peculiar way of expressing political resistance and had an unexpected massive impact. During GeziProtest many young creative artists, designers and activists responded to the overgrowing photograph sharing on social media and used photographs taken at the resistance in their protesting art. Private photographic portraits as an agent of resistance have been creatively modified, recreated, rematerialized and circulated in distinct ways: in actual public spaces and in virtual spheres as diverse online digital re-mastering. Some of the powerful moments captured during the resistance, have been used repeatedly in different media and gained an iconic status and become the recognized symbol of the movement. These images have been shared often alongside the hashtag"\#GeziParkResist" and "\#OccupyGezi". One famous icon is the image of a policeman using pepper gas spray, from a very close distance to a face of a woman in a red cotton summer dress. The contrast between the masked policemen with a protective outwear and the woman with a casual red dress who does not have a violent or threatening body posture creates a powerful image. Her hairflitting with the force of the fired pepper

\footnotetext{
${ }^{2}$ The original Turkish phrase with an intentional typo mistake reflects an opposition both to the police force and to the conventional slogans writes; "Yeterartıkya! Polis çağrıcam".

3 The original Turkish phrase writes; "Memurbey, Bi’ şeydüşürdünüz!”.

4 The original Turkish phrase writes; "Korkma la! Biziz, halk".

5 The original Turkish slogan is "Bu gazıbanalütfedermisiniz?".

6 TOMA is an abbreviation of "Toplumsal Olaylara Müdahale Aracı" (Intervention Vehicle to Social Events) used by Turkish police force and Gendarmerie and is an armored water cannon particularly designed for riot control and was often used at the time of Gezi Park Resistance.

7 The original Turkish phrase is " 3 gündüryıkanmıyoruz TOMA neredesin?".
} 
gas spray is used to characterize the growing police violence. This photograph has been modified and the city walls have been stenciled with the image of this woman in red. "Where does the power of this image lie? What does the body of a red-dressed woman signify?" asks Baydar (2015, p. 4). For her (2015) in the popular imagery, red is a color that is related to female sexuality. The woman in red is also directly linked to the realm of Femme Fatales and signifies the dark side (p. 4). Therefore, became a direct target for a patriarchal gaze, which made this a perfect symbol of Gezi Resistance. For Kayabalı (2013) the size of the woman, which is depicted noticeably larger than the policeman, is "symbolizing the growth of the resistance as the police violence became rougher".

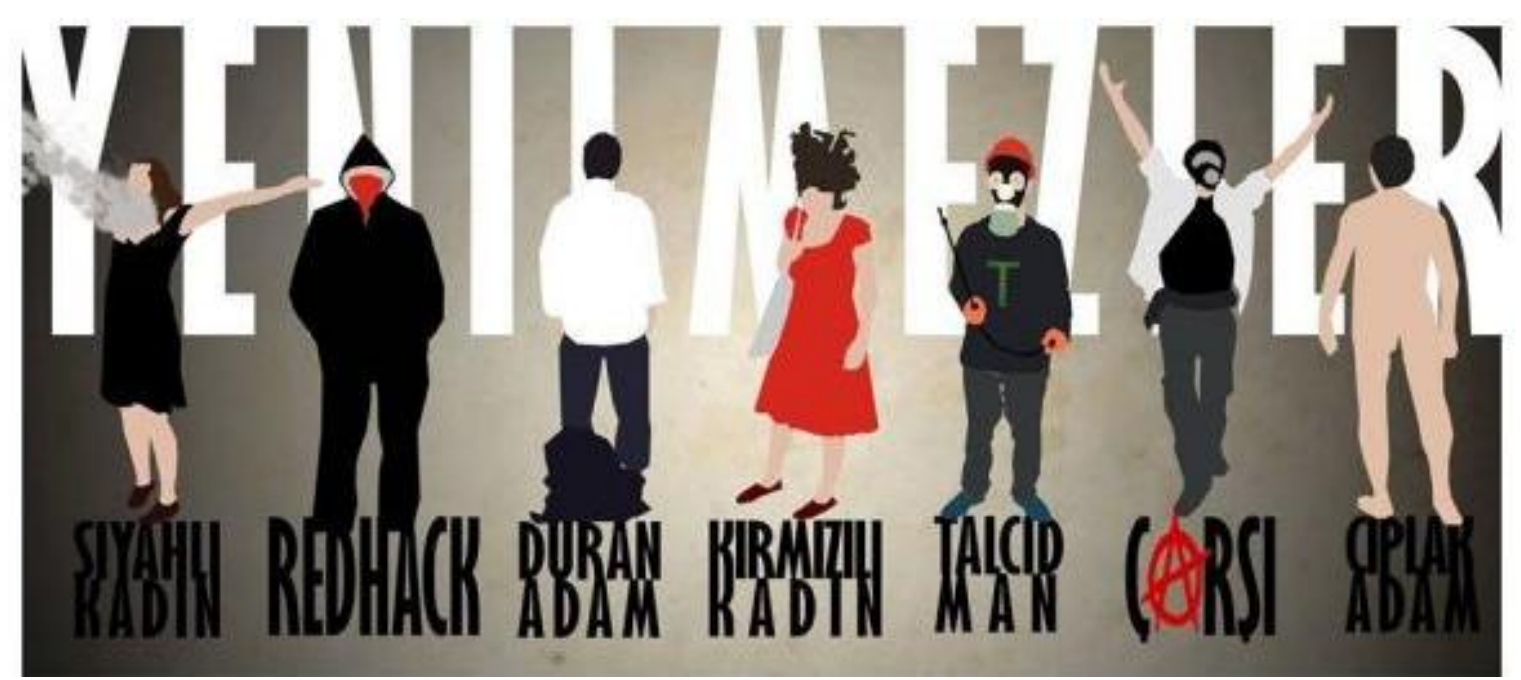

Figure 1. An illustration that shows the invincible characters of the Occupy Gezi Movement; woman in black, Redhack, standing man, the woman in red, Talcid man, Çarşı and the naked man. ${ }^{8}$

Like the woman in red (the 4th illustration from left in Figure 1), throughout the protest, there have been many interesting photographs that captured characters, which turn out to be heroes of the resistance for the protesters. Their photographic images have been turned to illustrations and circulated naming them as the "invincible" (yenilmezler) (see Figure 1). The other invincible is called "the woman in black", who throw herself in front of a water cannon, with her arms wide open, exposing her chest. This photograph, turn out to be the symbol of non-violent resistance against disproportionate use of police force. One image depicts a man who stands in the middle of Taksim Square. This image has been circulated along with a hashtag\#ResistStandingMan. This lone protester stood hours without moving as a part of his ultra-pacifist demonstrative performance staring at the Turkish flags on the Atatürk Cultural Center. Standing man and his passive protest have been recognized immediately and protester started to stand still in public spaces. There have been various kinds of creative protests that have been associated with an activist figure. Such as the man who reads books to the policeman that are waiting armed, the Talcid man with his curious outfit who tries to help the ease the pain of protesters, or the man who plays his guitar in front of the police barricades. These portraits used in the art of the resistant groups are all reinterpreted versions of photographs taken during the protests. Yet there is one peculiar instance, which has labeled the Occupy Gezi Movement that might be focused further more: the death of Berkin Elvan and his portrait photograph. Berkin Elvan is a teenage boy who has struck in the head by a tear gas canister, fired by police, while on his way to buy bread for his family in his

\footnotetext{
${ }^{8}$ Figure 1 Retrieved from http://norhetorike.com/2013/06/26/kate-cullen-siyahli-kadin-the-woman-in-black/,02,2016.
} 
own neighborhood, during the Gezi protests. He stayed in coma 269 days and died after turning 15 . This case has been a catalyst for further demonstrations against Turkey's ruling party and turned Berkin's high-spirited face and dark eyebrows, to one of the strong symbols of the resistance. ${ }^{9}$ In this occasion, different than the heroes and invincible characters of the movement depicted in Figure 2, Berkin Elvan has stayed at coma and, after all, has passed away in his early age. The reproduced images of Berkin Elvan have been taken from his Facebook profile. Different from the heroic images that were captured during the protests, Berkin Elvan's smiling face has once been captured as snapshots as a part of his daily life on 31.12.2012 at 11:44 as the date on the photograph displays. He smiles at the camera, holding his friends little fingers in a peculiar way most probably because the photograph is captured them performing the traditional dance halay, at the classroom which one can see the blackboard and framed photograph of Atatürk in the background. He is posing spontaneously to commemorate the moment (see Figure 2). Such a common image can be found in various variations in many Facebook and family albums. Yet, this smiling face of an ordinary boy gained an iconic character and a historical importance.

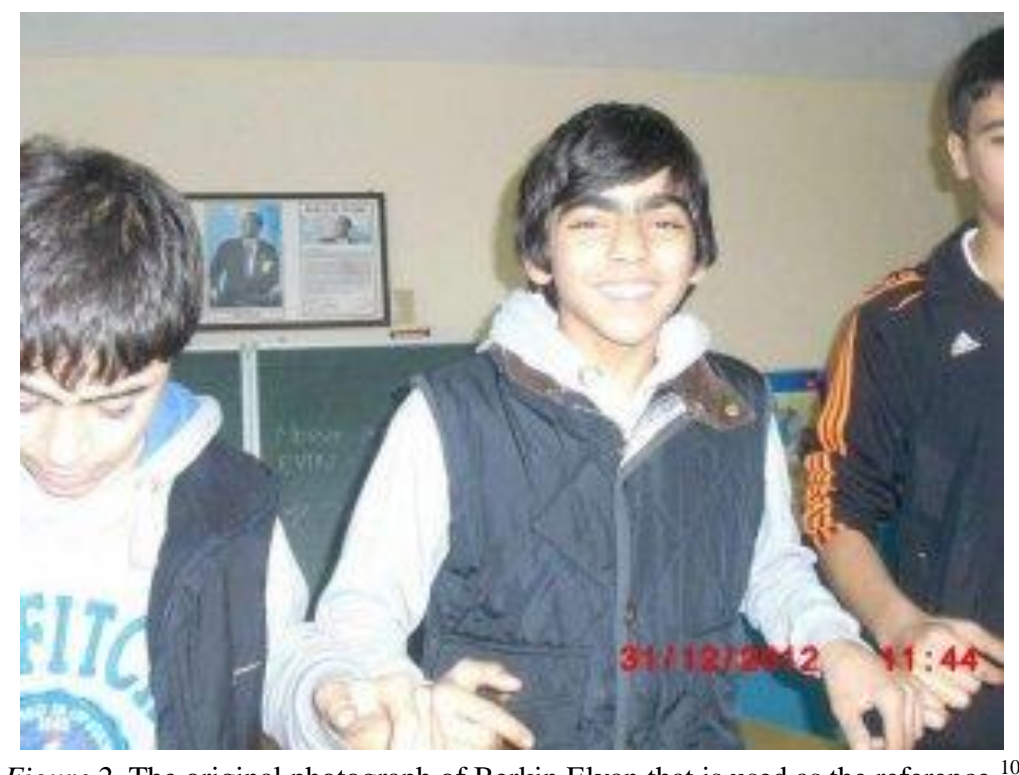

Figure 2. The original photograph of Berkin Elvan that is used as the reference. ${ }^{10}$

In this case, one encounters a transformation of the single analog vernacular photograph of Berkin Elvanto various digital versions and continuous re-interpretation and re-materialization (see Figure 3). In this ordinary snapshot of Berkin Elvan, and its digital incarnations, not only a teenage boy is depicted. It does not only show how he looks like, rather it represents broader and intense meanings about protests towards the ruling government. What makes this photograph actually iconic is that it does not display a portrait of an ordinary boy but represents hope against the violence that stole his young life. In order to be an iconic image, this candid image of Berkin Elvan deprived of its original context and its previous social meanings as a memory photograph.

According to Elizabeth Edwards (1999) photographs "reinforce networks and identity built on the memory to which they relate, positioning individuals vis á vis the group, linking the past, present and perhaps implying a

\footnotetext{
9 There have been many discussions whether Berkin Elvan was a protester of the Gezi Park Movement or was accidently there during the protests as he was out to buy bread. Turkish Prime Minister Tayyip Erdoğan claimed that Berkin Elvan was a terrorist depending on a photograph where his face covered by a scarf, reports Hasnain (2014) in Spiegel Online.

10 Figure 2 Retrieved from http://www.sozcu18.com/berkin-elvan-olumle-pencelesiyor-11160h.htm,02.2016.
} 
future" (p. 226). In this case the initial integral meaning of the photograph, as a private memory picture as seen in Figure 3, loses its connection with the time of its production; the moment Berkin Elvan was in front of the camera with his schoolmates. For Barthes (1981) "what the Photograph reproduces to infinity has occurred only once: the Photograph mechanically repeats what could never be repeated existentially" (p. 4). This "that has been" (Barthes, 1981) quality of the photograph that proves that the subject was there at that particular moment, in this case becomes unimportant. Strangely, this is not what Berkin Elvan's portrait photograph recalls anymore. The moment that could never be repeated existentially is not the moment this image is working to signify, but it works to remind many of a totally different time, context, and memory. Kember (2008) writes that "memory, in the abstract, exists somewhere between the particular subject who remembers, and the particular object that stimulates the remembrance. Memory, in the abstract, exists virtually—as a potential and endless reserve of actual memories - but its existence is real" (p. 179). In the case of Berkin Elvan's portrait, he, as the particular subject who is supposed to remember, is not there anymore to recall the actual moment. In material sense, the original image has been lost its authenticity as it has been mechanically and digitally modified several times. This image is disconnected from its original context/time since it started to signify a broader meaning that the public associates with the resistance. Having pointed the transformation of this simple image of a boy smiling to the camera possibly in the hands of his classmate, to an icon, one should also bring up the long termed discussions about the auraticquality of the image. This long debated issue has started with the discussion of Walter Benjamin (1969) who has famously discussed the loss of aura and authenticity in the mechanically reproduced work of arts and print objects. Roland Barthes (1981) makes the concept of aura as one of the major focus of photography theory. In Bartesian account, photographs have been associated with authenticity because of its close relation to reality and to its referent and were seen as an optical medium of storage that records what is in front of the lens. For him (1981), photography is "an emanation of the referent". As is well known, in the semiotic system of Charles Pierce, an indexical sign has a physical connection to its referent. Different than painting and other mediums of representation it has been argued to have a special power: its indexical quality that goes beyond re-presentation. Photographs are different because it leaves traces, imprints from the object and stored on the light sensitive surface (Barthes, 1981; Sontag, 1979). Because of this authenticity that comes from its indexical peculiarity, analogue photographs have an auratic quality and a close relation to the subject represented as Roland Barthes argues. Benjamin (1969) suggests, this authenticity and aura of photographs have been destroyed when it is mechanically reproduced. This discussion of destruction of auratic value in photographs has been also carried to digital reproduction. Yet some scholars, who are making the reassessment of Benjamin's argument in the context of the recent technological and social developments, argued that mechanical photography begins to re-gain an "auratic" value in contrast to Benjamin's view. Theorists that work on digital photography such as Lister (2007) and Manovich (1995) have supported the idea that actually digital reproduction might stimulate and increase the auratic quality of the images. Baecker (2003) suggests that "aura" is not disappearing like the way Benjamin suggested. In contrast, there is almost an inevitable reappearance of "aura" as a result of technological developments (p. 9). Similarly, Huyssen (2003) suggests that "today, digitization makes the 'original' photograph auratic" (p. 20). In this sense, according to Ryzova (2015, p. 42) actually not only certain photographs of certain notable individuals are iconic, but actually, all photographic images have an iconic value. The photo-theoretical writing focuses on the indexical quality of the photographs privileges the referent associated with a photographic object. This perceived one-to-one correspondence between photograph andreferent comes from their quality as mechanical prints of 
the real that carries the physical traces of the referent that is undoubtedly in front of the camera. According to Ryzova (2015) "Iconicity means the capacity to carry meanings much wider than what is actually depicted. Iconicity of photographs is a quality that goes well beyond their indexical referents and thus exceeds their status as photographs, and links the image not to its content but to social values" (p. 45). In this sense, Berkin Elvan's photographs as simple vernacular images of a teenage boy does not have a personal memorative drive anymore but become an iconic image that have a performative purpose that goes beyond being referential and becomes symbolic, iconic and metonymic. The image that gains an iconic value does not lose its auratic value, yet what it lost is its earlier context and associated meaning as an object of personal memory. Photography historian Vicky Goldberg describes a term what she calls "secular icon" for images with powerful symbolic influence just like Berkin Elvan's photographs, She (2000) remarks:

I take secular icons to be representations that inspire some degree of awe perhaps mixed with dread, compassion, or aspiration - and that stand for an epoch or a system of beliefs. Although photographs easily acquire symbolic significance, they are not merely symbolic; they do not merely allude to something outside themselves ... for photographs intensely and specifically represent their subjects. But the images I think of as icons almost instantly acquired symbolic overtones and larger frames of reference that endowed them with national or even worldwide significance they concentrate the hopes and fears of millions and provide an instant and effortless connection to some deeply meaningful moment in history. (Brink, 2000, p. 137)

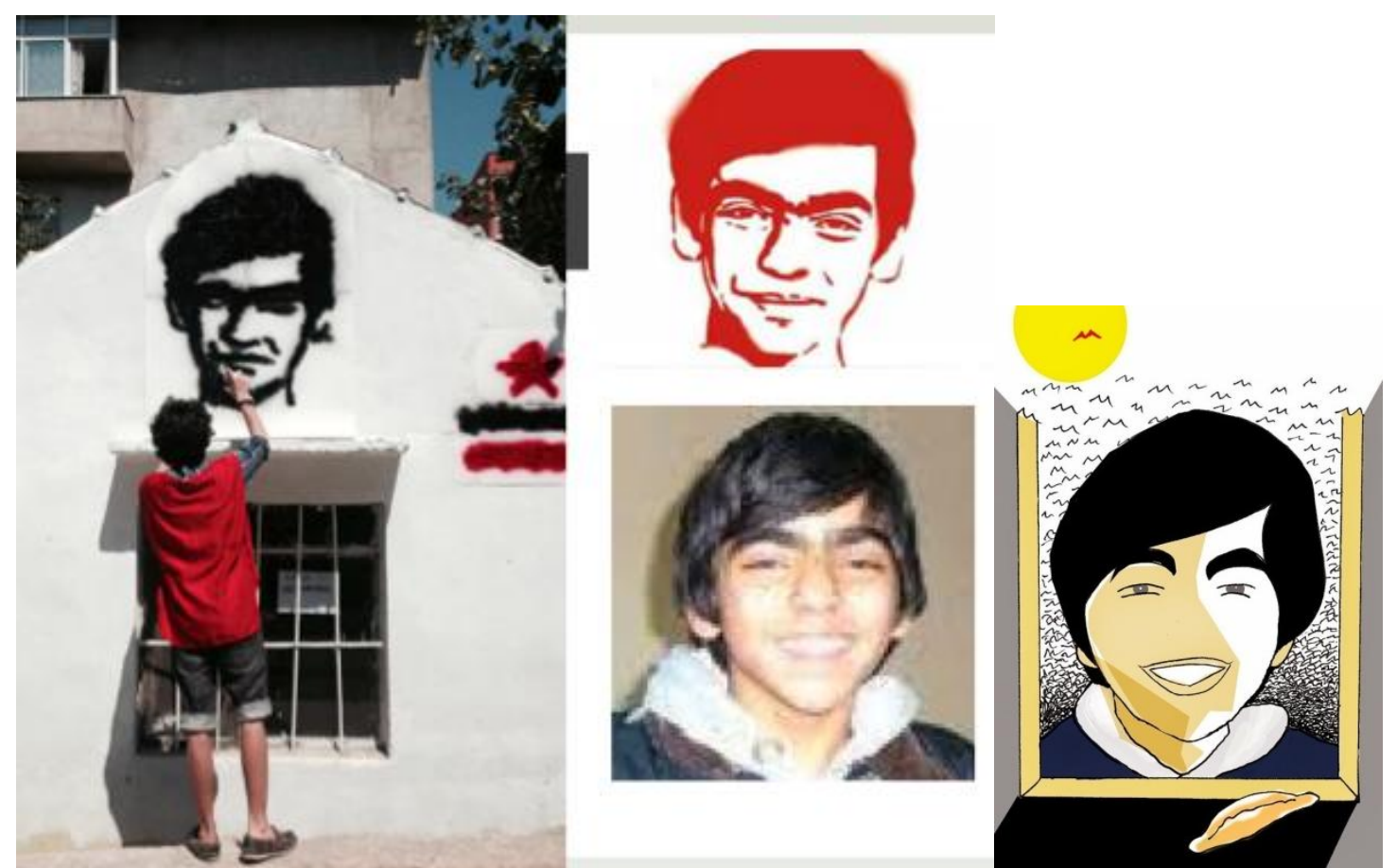

Figure 3. Berkin Elvan's original portrait that is cropped from a wider photograph and its reincarnation as a stencil and an illustration. Illustration by Muammer Koybaş. ${ }^{11}$

In this sense, this single image of the boy stands much more than a portrait depicted and instead turns out to be including visual codes that articulate social values and relationships of the peculiar time of resistance in Turkey and can be regarded as a "secular icon" that has a great symbolizing power. In a similar view, Hariman

${ }^{11}$ Figure 3 Retrieved from http://www.gazeteciler.com/gundem/berkin-elvanin-cenazesi-nereden-ne-zaman-kaldirilacak-74853h.html, 02.2016 and from www.kotbasartcolors.blogspot.com.tr,02.2016. 
and Lucaites (2007) argue that photographs as icons achieve their effectiveness through their visual expressiveness and wide circulation (p. 12). In this case of Berkin Elvan is the online environment through countless acts of posting, sharing and commenting in social media. Apart from its vast popularity, the iconic image creates an emotional impact and its reinterpretations and reworking (Figures 3 and 6) intensify its power to symbolize. So, one can say that this image started to have a digital and social after live as an icon of the resistance through the iconized imagery as illustrations and drawings; as stencils and graffiti at streets which recapitulate or re-enact social articulations freed from its original context.

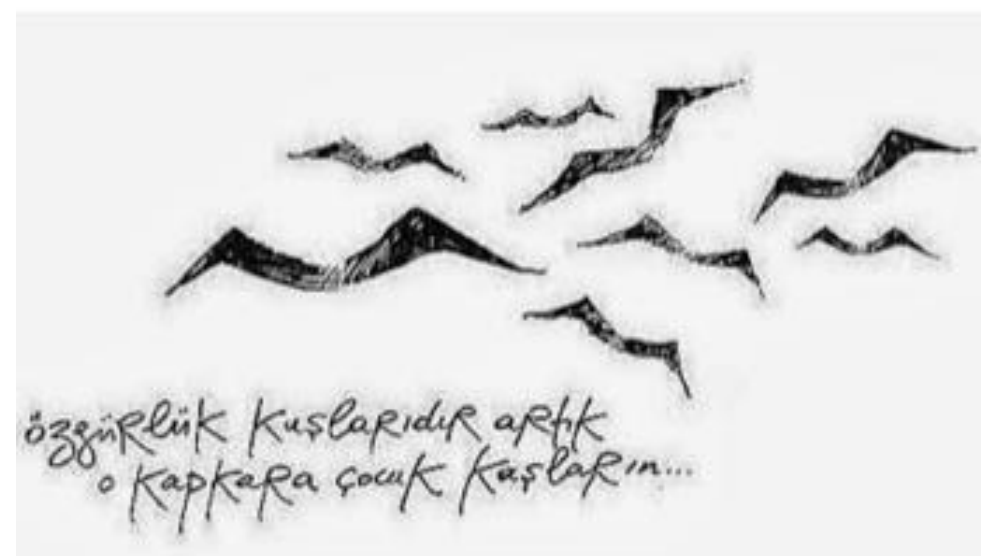

Figure 4a. "Your black child eyebrows are now birds of freedom," writes the sketch. ${ }^{12}$

Figure 4b. Berkin Elvan illustrated as an angel who holdsa loaf of bread. The hashtag writes: \#berkinelvanisimmortal. ${ }^{13}$

Instead of being in the pages of the precious family albums, this image started to decorate the walls of the streets and screens. Berkin Elvan's image's powerful message has crossed the borders of the country and not only the streets of Turkey were populated by Berkin Elvan's images but also walls of Greece were also hosting Berkin Elvan's stencilsand posters. As an example of this image's social afterlife, one can give the intertextual connection created with the death of fifteen-year-old Alexis Grigoropoulos who has also been hit by the police in 2008. The death of Alexis had also had started extensive demonstrations in Greece. On 13 March 2014,

\footnotetext{
${ }^{12}$ Figure 4a Retrieved from http://everywheretaksim.net/category/images/berkin-elvan, 02.2016.

${ }^{13}$ Figure 4b Retrieved from http://listelist.com/berkin-elvan-tasarim/?replytocom=5467, 02.2016.
} 
Turkish Journal Hürriyet published the news under the title "You are my brother Alexis, You are my brother Berkin" which have started to be used as a slogan and have been carried to social media and all over the streets of Turkey and Greece that displays images of Berkin and Alexis placed close to one another as banners, stencils and posters (see Figure 5). Konak and Dönmez (2015) discusses that this brotherhood have various meanings in the sense that "brotherhood in the age and in the manner of dying: hit by the police. Relating the long history among Greek and Turks, the authors read this brotherhood also as being 'brothers despite our differences"” (p. 37).

After gaining an iconic status, and become a recognized image worldwide, the re-workings of Berkin Elvan's portraits started to be minimal and metaphoric. His dark tick characteristic eyebrows are re-signified with a host of novel meanings and have been used figuratively. They are visually aligned with flyingbirds that symbolize peace and freedom (see Figure 4a). Additions have been made to his portrait photograph. The modified versions included a loaf of bread. He has been illustrated with the bread, as he was out to buy when he was shot (see Figure 4b).

The usage of bread is a crucial element in the context of Turkey since bread is a loaded symbol and regarded as a quasi-sacred object. It is the source of nourishment. It represents both human labor and God's grace through nature. Wasting bread is seen as a sin; therefore, wasting the life of a teenage boy is doubling the connotation of the bread. Not only bread is used in illustrations that are associated with Berkin Elvan, but also has been used in protests and his funeral (see Figure 5b). Berkin Elvan and bread protests started around the country and picked up through social media. People in public places sat with a bread and a picture Berkin Elvan's. It started with one person and spread to the country. People carried a loaf of bread in demonstrations and in some cases used red ink to symbolize the blood and their anger. To represent grieving, black ribbon is tied around the bread. His funeral became one of the biggest demonstrations in Turkey's recent history. Berkin Elvan's portrait has been carried as posters and framed photographs in political performances, carried around in public spaces during his funeral.

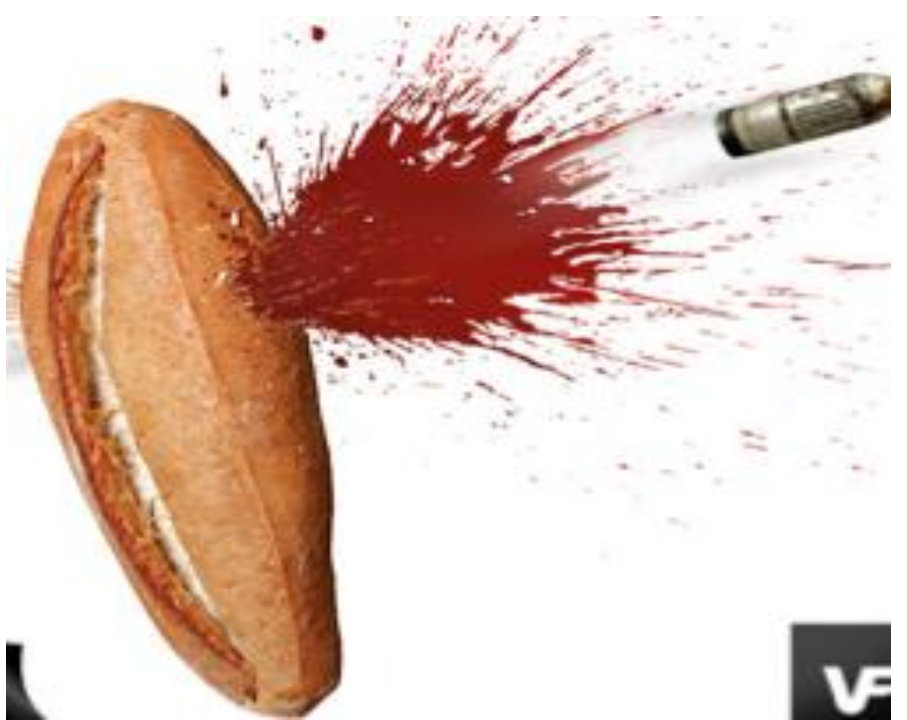

Figure 5a. A powerful poster that uses a load of bread interchangeable with Berkin's body that was hit by the tear gas canon. $^{14}$

${ }^{14}$ Figure 5a Retrieved from http://vagus.tv/2014/03/15/berkin-elvanin-ardindan/,02.2016. 


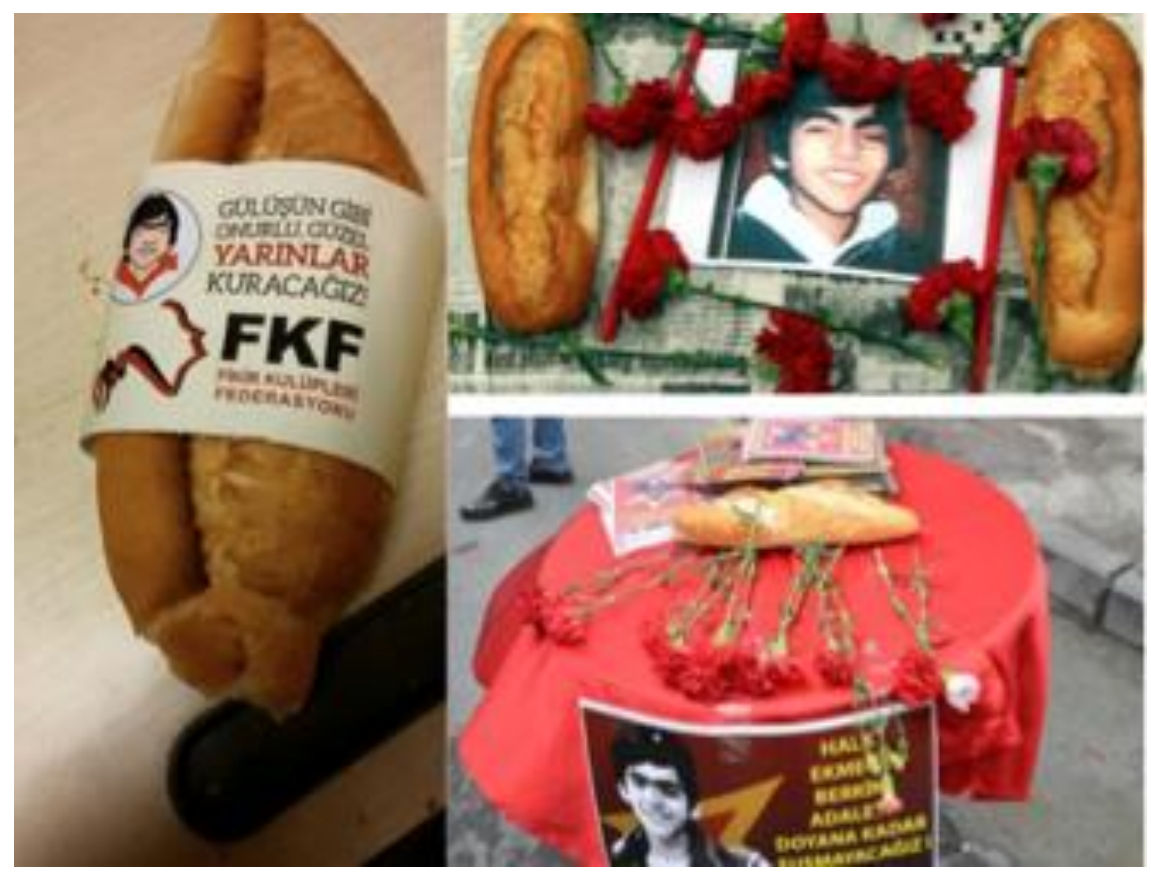

Figure $5 b$. Bread is used as a powerful symbol along with his photographs in demonstrations, Berkin Elvan's funeral, and protests. ${ }^{15}$

"Every photograph is a sign, above all, of someone's investment in the sending of a message", says Alan Sekula (1982, p. 87). Berkin Elvan's photographs become a powerful sign sending messages of Gezi Resistance. In this context a banner shared on the timeline of the Facebook public page account dedicated to Berkin Elvan, once again referring to popular texts describes what Berkin Elvan is for the resistance: "Batman is a sign. ' $\mathrm{V}$ ' of $\mathrm{V}$ for Vendetta is a sign. As for that Berkin Elvan is our symbol. He is the sign of the struggle for justice and democracy. We will not forget and will not let his memory fade". ${ }^{16}$ Edwards (1999) argues that, "the power of the nexus of image and material is made clearest in the destruction of the material object" (p. 226). Moreover, Mayor (1997) details this argument and evaluates the act of cutting, tearing or burning a photograph as a "violent, frightening hysterical action, which leaves behind indexical wounds and irreparable scars" (p. 19). In this sense, similar violent acts that include the destruction of the materiality of the iconic photograph of Berkin Elvan, thus the memory associated with, can be seen as an attack on the ideas that Berkin Elvan's imagery symbolize. ${ }^{17}$ In one poster, his body has been symbolically replaced with the quasi-sacred symbolic bread. Not only his body was hit by a tear gas canon, but as if all the ideas connected with the symbol of bread was also shot by the police and government that day (see Figure 5a). In this sense, although Berkin Elvan's actual body that is hit by a tear gas canon have faded away, but through his photographic body or metaphors aligned with him, he continues to shields ideas that are being fought for at Gezi Resistance. His portrait also has been printed as paper masks and has been used during commemorations replacing anonymous faces with the symbolic face of Berkin Elvan and turns the owner of the mask to a walking carrier of the message and a symbolic replica of

\footnotetext{
${ }_{15}$ Figure 5b Retrieved from http://www.haber8.com/guncel/ailesi-berkin-elvani-anlatti/haber-208333, 02.2016.

16 The original Turkish text reads: "Batman birsimgedir. $\mathrm{V}$ for Vendatta'nınV'sibirsimgedir.Berkin Elvan da bizimsimgemizdir.Adaletiçindemokrasiiçinsavaşınsimgesi.Unutmayacak, unutturmayacağız".

17 The Turkish Journal Milliyethave reported that the sculpture of Berkin Elvan at the park dedicated to him at Izmir has been vandalized and the police have opened an investigation. Retrieved from http://www.milliyet.com.tr/berkin-elvan-heykeline-cirkin-gundem-2026655/, on 10.02.2017
} 
Berkin Elvan (see Figure 6). In this sense, photographic icons include a process of cultural memory work and identification. As Yanay (2008) argues photographs are not only cultural artifacts or historical records but also is a part of collective national feelings of belonging or exclusion through ideological interpellation.

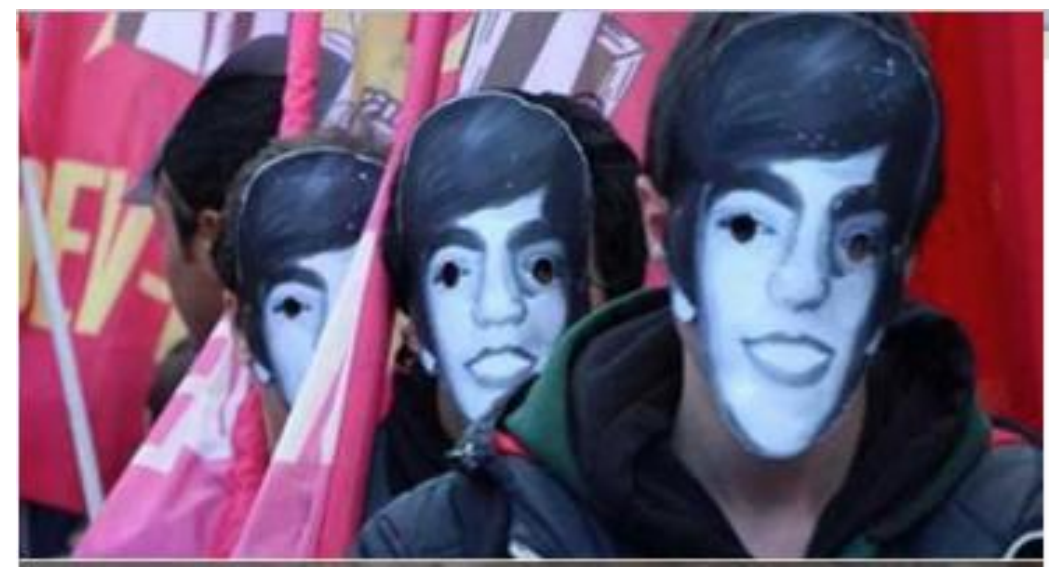

Figure 6. Berkin Elvan's mask used in demonstrations. ${ }^{18}$

The teenage boy's injury during the protests, his birthday while he was in a coma at the hospital, his death, funeral and commemorations have been stress points in which his ordinary photographic portrait have been modified and redesigned according to the occasion. One can say that his image has been re-signified, to take on new meanings and becomes an icon that becomes the youth symbol of the struggle. Don Slater (1999) recalling the practice of editing family albums as an operation of the memory, once said that "we construct ourselves for and through images" (p. 134). In this sense, by the reconstruction and reworking of Berkin Elvan's ordinary portrait photograph protesters of the Gezi Resistance actually, construct a future memory in the photographic practice of the present.

\section{References}

Baecker, D. (2003). The unique appearance of distance. In H. U. Gumbrecht, \& M. Marrinan (Eds.), Mapping Benjamin: The Work of Art in Digital Age (pp. 9-24). Stanford: Stanford University Press.

Barthes, R. (1981). Camera Lucida. New York: Hill and Wang.

Baydar, G. (2015). Embodied spaces of resistance. Women's Studies International Forum, 50, 11-19.

Benjamin, W. (1969). The work of art in the age of mechanical reproduction. New York: Schocken Books.

Brink, C. (2000). Secular Icons: Looking at Photographs from Nazi Concentration Camps. History \& Memory, 12(1), 135-150.

Çetin, G. (2013). Irony as a subversive tool in Gezi Park Protests and Politics. Retrieved from https://www.academia.edu/9352842/The_Language_of_Dissent_Irony_as_Int erruption_in_Gezi_Park_Protests

Edwards, E. (1999). Photographs as objects of memory. In M. Kwint, C. Breward, \& J. Aynsley (Eds.), Material Memories (pp. 221-236). Oxford: Berg.

Eken, B. (2014). The Politics of the Gezi Park Resistance: Against Memory and Identity. The South Atlantic Quarterly, 113(2), 427-436.

Emre, Ö. P., Barış, Ç., \& Gülüm, Ş. (2014). Humorous Form of Protest: Disproportionate use of intelligence in Gezi Park's resistance. Retrived from https://www.academia.edu/5135723/Humorous_form_of_protest_Disproportio nate_use_of_intelligence_in_Gezi_Park_s_Resistance

Gruber, C. (2013). The visual emergence of the occupy Gezi movement. Retrieved from http://www.jadaliyya.com/pages/index/12714/the-visual-emergence-of-the-occupy-gezi-movement-p

18 Figure 6Retrieved from http://www.ntv.com.tr/turkiye/berkin-elvan-eyleminde-10-gozalti,to9xaZcW4kqmP6g3HziHZw, 02.2016 . 
Hariman, R., \& Lucaites, J. L. (2007). No caption needed: Iconic photographs, public culture, and liberal democracy. Chicago: Chicago University Press.

Hasnain, K. (2014). Türkei: ErdogannennttotenJungen “Terrorist” (Turkey: Erdoğan called dead boy "terrorist”). Retrieved from http://www.spiegel.de/politik/ausland/tuerkei-erdogan-nennttoten-15-jaehrigen-berkin-elvan-terrorist-a-958758.html

Huyssen, A. (2003). Present pasts: Urban palimpsests and the politics of memory. Stanford: Stanford University Press.

Karakayal1, S., \& Yaka, Ö. (2014). The spirit of Gezi: The recomposition of political subjectivities in Turkey. New Formations, $83,117-138$.

Kayabal1, Y. (2013). Protest Art in Real Time. Creative Review, 36(8), 66-76.

Kember, S. J. (2008). The virtual life of photography. Photographies, 1(2), 175-203.

Konak, N., \& Dönmez, R. Ö. (2015). Waves of social movement mobilizations in the twenty-first century: Challenges to the Neo-liberal world order and democracy. Lanham: Lexington Books.

Lister, M. (2007). A Sack in the Sand: Photography in the age of information. Convergence, 13(3), 251-274.

Manovich, L. (1995). The paradoxes of digital photography. In V. Amelunxen, S. Iglhaut, \& F. Rotzer (Eds.), Photography After Photography. Munich: Verlag der Kunst.

Mavor, C. (1997). Collecting Loss. Cultural Studies, 11(1), 111-137.

Ryzova, L. (2015). Unstable icons, contested histories: Vintage photographs and neoliberal memory in contemporary Egypt. Middle East Journal of Culture and Communication, 8, 37-78.

Sekula, A. (1982). On the invention of photographic meaning. In V. Burgin (Ed.), Thinking Photography (pp. 84-109). London: Palgrave Macmillan.

Slater, D. (1995). Domestic photography and digital culture. In M. Lister (Ed.), The Photographic Image in Digital Culture (pp. 129-146). London: Routledge.

Sontag, S. (1979). On Photography. London: Penguin Books.

Yanay, N. (2008). Violence Unseen: Activating National Icons. Cultural Studies, 22(1), 134-158. 